Bryn Mawr College

Scholarship, Research, and Creative Work at Bryn Mawr

College

Political Science Faculty Research and Scholarship

Political Science

2007

\title{
The Political Economies of Broadband Development in Korea and Japan
}

Kenji Kushida

Seung-Youn Oh

Bryn Mawr College, soh03@brynmawr.edu

Let us know how access to this document benefits you.

Follow this and additional works at: http://repository.brynmawr.edu/polisci_pubs

Part of the Political Science Commons

\section{Custom Citation}

K. Kushida and Seung-Youn Oh, "The Political Economies of Broadband Development in Korea and Japan," Asian Survey 47.3 (2007): 481-504.

This paper is posted at Scholarship, Research, and Creative Work at Bryn Mawr College. http://repository.brynmawr.edu/polisci_pubs/29

For more information, please contact repository@brynmawr.edu. 
The Political Economies of Broadband Development in Korea and Japan Author(s): Kenji Kushida and Seung-Youn Oh

Source: Asian Survey, Vol. 47, No. 3 (May/June 2007), pp. 481-504

Published by: University of California Press

Stable URL: http://www.jstor.org/stable/10.1525/as.2007.47.3.481

Accessed: 09/10/2015 08:51

Your use of the JSTOR archive indicates your acceptance of the Terms \& Conditions of Use, available at http://www.jstor.org/page/info/about/policies/terms.jsp

JSTOR is a not-for-profit service that helps scholars, researchers, and students discover, use, and build upon a wide range of content in a trusted digital archive. We use information technology and tools to increase productivity and facilitate new forms of scholarship. For more information about JSTOR, please contact support@ jstor.org.

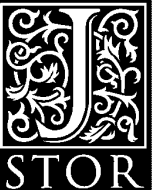

University of California Press is collaborating with JSTOR to digitize, preserve and extend access to Asian Survey.

http://www.jstor.org 


\section{THE POLITICAL ECONOMIES OF BROADBAND DEVELOPMENT IN KOREA AND JAPAN}

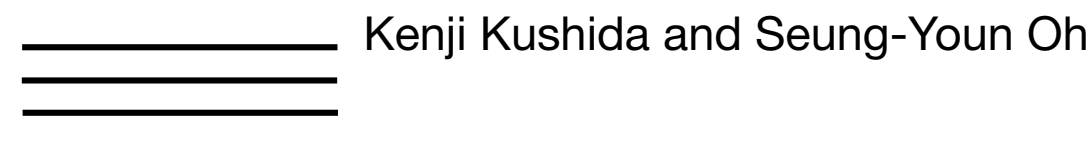

\section{Abstract}

South Korea's and Japan's telecommunications sectors developed rapidly, especially in high-speed, low-priced broadband. We argue that both countries are engaged in strategic liberalization, fostering competition to reach specific goals. However, different political dynamics pushed their initially similar policy regimes apart. Korea retained its managed competition regime while Japan experienced a regime shift.

Keywords: information communications technology, Japan, South Korea, political economy, broadband

\section{Introduction}

Information and Communications Technology (ICT) has been recognized worldwide as not only a lead sector but a broadly transformative one, capable of driving productivity, innovation, and growth in a wide range of industries. ${ }^{1}$ Although most advanced industrial countries have striven to develop their ICT sectors, the rapid ICT development of Japan and Korea since the late 1990s has propelled them to the global forefront of high-speed landline

Kenji Kushida and Seung-Youn Oh are doctoral students in the Department of Political Science at the University of California, Berkeley. This article derives from their publication, "Understanding South Korea and Japan's Spectacular Broadband Development: Strategic Liberalization of the Telecommunications Sectors," University of California at Berkeley, Berkeley Roundtable on the International Economy (BRIE) Working Paper, no. 175 (2006). Emails: <kkushida@berkeley.edu>,<ohusky@berkeley.edu>.

1. Stephen Cohen, J. Bradford DeLong, John Zysman, Tools for Thought: What Is New and Important About the "E-Conomy" (Berkeley: BRIE, 2000).

Asian Survey, Vol. 47, Issue 3, pp. 481-504, ISSN 0004-4687, electronic ISSN 1533-838X. (C) 2007 by The Regents of the University of California. All rights reserved. Please direct all requests for permission to photocopy or reproduce article content through the University of California Press's Rights and Permissions website, at http://www.ucpressjournals.com/reprintInfo.asp. DOI: AS.2007.47.3.481. 
and wireless Internet connectivity. ${ }^{2}$ In particular, their development of broadband markets within a few short years, despite neither country's having been a leader in the U.S.-initiated Internet revolution, was nothing short of stunning.

Successfully developing a new lead sector late in the game is nothing new to Japan and Korea. Both saw rapid postwar economic development driven by industrial catch-up efforts in lead sectors - textiles, followed by steel, autos, electronics, and semiconductors. However, the two countries' rapid development of broadband opens new questions in longstanding debates. Much ink has been spilled in trying to understand the nature of state-market interactions and the relationship of these interactions to economic growth. ${ }^{3}$ The development of broadband occurred well after the heyday of both countries' heavyhanded, interventionalist, government-driven "developmental" regimes, and yet both governments touted national strategies for ICT development. At the same time, dynamic broadband service markets with fierce competition could be found in both countries.

Exactly how did the governments and markets interact in the process of Japan and Korea becoming frontrunners in broadband? How similar were these respective interactions? What were the politics and institutions driving each government's policymaking - and how do they compare with one another? This paper seeks to answer these questions by analyzing interactions between institutional structures, the logic of telecoms policymaking, regulatory regimes, and market dynamics.

In this article, we first present empirical data elaborating on the nature and extent of each country's broadband development. Second, we examine two major perspectives, market-led and state-led; these underlie not only most broad analyses of Japanese and Korean postwar economic development but also underpin existing explanations of their broadband development. We then present our own synthesis, strategic liberalization, which focuses on the interaction of the two perspectives and is capable of reconciling the seemingly contradictory evidence that supports each. Third, we examine the development of broadband in Japan and Korea by closely tracing (1) the institutional origins of the telecommunications sector and the political dynamics arising from these origins; ${ }^{4}(2)$ the regulatory frameworks that emerged as each country began liberalization; and (3) the market dynamics of broadband services as they

2. Following the Organization for Economic Cooperation and Development (OECD), we refer to "broadband" as services offering more than $256 \mathrm{kbps}$ (kilobytes per second) downstream, excluding ISDN (Integrated Services Digital Network), discussed later. See OECD, The Development of Broadband Access in OECD Countries (Paris: OECD, 2002), p. 6.

3. For an overview, see Robert Wade, "East Asia's Economic Success: Conflicting Perspectives, Partial Insights, Shaky Evidence,” World Politics 44:2 (1992), pp. 270-320.

4. "Institutions" is a widely contested concept, but in this paper we refer to formal organizations. 
were shaped by and, especially in Japan's case, helped shape the regulatory framework.

We argue that Japan and Korea experienced a broadly similar outcome of rapid broadband development through somewhat different trajectories of government-market interactions. The two countries' institutional configurations at the inception of the sector differed in terms of (1) the relative power of the lead bureaucracy (i.e., having charge of the sector) over the incumbent telecom operator and (2) the bureacracy's role in broader national politics. These differences led to a different set of political dynamics in each country. Despite the existence of similar regulatory regimes of "managed competition" as both countries initially liberalized the sector, divergent dynamics of telecommunications policymaking drove their regulatory regimes in different directions. We argue that Korea's broadband networks and service markets grew out of its existing "managed competition" regime, while Japan's broadband markets developed during the course of a regulatory "regime shift."

\section{Rapid Broadband Development in Korea and Japan}

Korea's and Japan's leadership in broadband came within four years of the inception of their broadband markets. Neither country had broadband before 1998 , but by 2002 Korea had far exceeded all other nations in terms of penetration, and Japan led the world in speed and price (see Table 1). ${ }^{5}$

Korea moved first, with the rapid growth of DSL (Digital Subscriber Line), a technology that sends high frequency signals over existing copper telecommunications infrastructure. With consumers enjoying the cheapest prices in the world, Korea's broadband penetration became the highest worldwide by 2001 and has remained so to date. Considering that there was no market for broadband before 1998, the fact that 70 out of 100 households sported broadband subscriptions by 2002 is nothing short of astonishing (see Table 2). ${ }^{6}$ In the one year between 1999 and 2000, the number of DSL subscriptions in Korea rose from 97,000 to 2.4 million; cable modem subscriptions increased from 17,000 to 1.6 million. $^{7}$

Japan followed suit in the early 2000s (see Table 3). In 1999, when DSL was first introduced, Japan was among the most expensive OECD countries

5. No single "best indicator" of national broadband performance exists. Available measures include availability, penetration, capacity/speed, price. Martin Fransman, "Introduction," in Global Broadband Battles: Why the U.S. and Europe Lag while Asia Leads, ed. Martin Fransman (Stanford, Calif.: Stanford University Press, 2006), p. 7.

6. National Computerization Agency (NCA), Informatization White Paper 2004: Broadband IT Korea (Seoul: NCA, 2004), p. 15.

7. OECD, "The Development of Broadband Access," p. 13. 
TABLE 1 Broadband Penetration Rate Per 100 Inhabitants

\begin{tabular}{llrrrll}
\hline & 2000 & 2001 & 2002 & 2003 & 2004 & 2005 \\
\hline Korea & 9.2 & 17.2 & 21.8 & 24.2 & 24.9 & 25.4 \\
Japan & 0.2 & 2.2 & 6.1 & 10.7 & 15 & 17.6 \\
USA & 2.3 & 4.5 & 6.9 & 9.7 & 13 & 16.8 \\
OECD average & 1.27 & 2.9 & 4.9 & 7.3 & 10.3 & 13.6 \\
\hline
\end{tabular}

SOURCE: OECD Telecommunications Database 2005 and OECD, OECD Key ICT Indicators, $<$ http://www.oecd.org/sti/ICTindicators >, accessed June 2, 2006.

TABLE 2 Broadband Subscriptions, Korea 1999-2005 (millions)

\begin{tabular}{lcccccrr}
\hline & 1999 & 2000 & 2001 & 2002 & 2003 & 2004 & 2005 \\
\hline Total broadband & - & 3.92 & 8.14 & 10.4 & 11.61 & 12.17 & 12.46 \\
Cable Internet & 0.17 & 1.56 & 2.94 & 3.55 & 3.94 & 4.24 & 4.15 \\
DSL lines & 0.97 & 2.35 & 5.18 & 5.66 & 6.57 & 6.72 & 6.42 \\
Other & - & 0.01 & 0.03 & 1.18 & 1.09 & 1.21 & 1.88 \\
\hline
\end{tabular}

SOURCES: 1999-2003: OECD 2005; 2004: Ministry of Information and Communications ([Korea]/MIC); 2005: NCA. NOTE: The number for 2004 is one month after end FY 2004; 2005 is end of FY 2005.

TABLE 3 Broadband Subscriptions, Japan 1999-2005 (millions)

\begin{tabular}{lccllrrr}
\hline & 1999 & 2000 & 2001 & 2002 & 2003 & 2004 & 2005 \\
\hline Total broadband & - & 0.63 & 2.83 & 7.81 & 13.64 & 18.66 & 22.37 \\
Cable Internet & 0.15 & 0.63 & 1.3 & 1.95 & 2.48 & 2.87 & 3.23 \\
DSL lines & $<.01$ & 0.01 & 1.52 & 5.65 & 10.27 & 13.33 & 14.48 \\
FTTH & - & - & 0.07 & 0.42 & 1.45 & 2.43 & 4.64 \\
\hline
\end{tabular}

SOURCES: 1999-2003: OECD 2005; 2004-05: (Japan) MIC.

NOTE: $F T T H=$ Fiber-to-the-Home. For FTTH, 2001-03 indicates end of FY rather than calendar year. 
TABLE 4 Comparison of Prices Per 100 Kbps, as of July 2003

\begin{tabular}{llllll}
\hline Country & US\$ & Country & US\$ & Country & US\$ \\
\hline Japan & 0.09 & Singapore & 2.21 & Netherlands & 3.36 \\
Korea & 0.25 & New Zealand & 2.71 & U.S. & 3.53 \\
Belgium & 1.15 & China & 3.07 & Germany & 4.42 \\
Hong Kong & 1.27 & Canada & 3.25 & &
\end{tabular}

SOURCE: (Japan) MIC, Joho Tsushin Hakusho Heisei 16 Nen Ban [Information and Communications White Paper 2004] (Tokyo: Ministry of Internal Affairs and Communications, 2004), p. 6, based on International Telecommunications Union (ITU) data.

in terms of Internet access. However, penetration grew rapidly after 2000 , with the number of DSL subscriptions between the end of December 2000 and June 2001 increasing by over 4,000\%. ${ }^{8}$ By 2002 Japan had the lowest prices for DSL in the world (see Table 4) as well as a market for FTTH services, which are high-speed fiber optic lines connected directly to households. FTTH services, offering transmission speeds of up to $100 \mathrm{mbps}$ (megabytes per second) (several times that of DSL), gave Japan the fastest household broadband networks worldwide. ${ }^{9}$ At the end of 2004, the ITU ranked Japan third in the number of total broadband subscribers, ${ }^{10}$ and by the end of 2005 over $44 \%$ of households had broadband access. Thus, by 2004, after a period of extremely rapid growth, the broadband networks of Korea and Japan were at the forefront of broadband penetration and price-performance. ${ }^{11}$

\section{Governments, Markets, and Development in Korea and Japan}

Our interest in understanding the two countries' rapid broadband development thrusts us into the ongoing debate over government-market interactions and economic growth. Whether in broader analyses of their spectacular postwar

8. Ibid., p. 14.

9. DSL services in Japan ranged from 1 to 8 mbps (megabytes per second) in 2001, increasing to $50 \mathrm{mbps}$ by 2003. Institute for Information and Communications Policy, Henbou Suru Kontentsu Bijinesu [Transforming content business] (Tokyo: Toyo Keizai Shinposha, 2005). Penetration figures do not capture the rapid increases in speed, a critical difference between Japan and the U.S.

10. Government of Japan, Ministry of Internal Affairs and Communications, Main Data on Information and Communications in Japan, <http://www.soumu.go.jp/joho_tsusin/eng/main_data. html >, accessed June 2, 2006.

11. By 2004, they had the lowest cost for $100 \mathrm{kbit} / \mathrm{s}$ as a percentage of monthly income. ITU, “Asia-Pacific Telecommunication Indicators 2004" (Geneva: International Telecommunications Union, 2004), p. 25. 
economic growth, their dramatic crises in the 1990s, or in more focused explanations of their broadband development, much intellectualizing falls within one or the other of two basic theoretical standpoints.

The first is a market-led perspective, rooted in ideas of neoclassical economics. From this perspective, competitive markets allocate resources most efficiently and are most conducive to growth. Most types of government intervention distort markets, thereby hampering growth. But globalization limits the ability of states to intervene, even to the point of rendering states irrelevant. ${ }^{12}$ Analyses from this vantage point contend that competitive markets were the primary driver of postwar economic growth in Korea and Japan. Government interventions were either limited, unsuccessful, and/or ultimately contributed to the economic crises there in the $1990 \mathrm{~s} .{ }^{13}$ According to this logic, the two countries' broadband development had to be driven by competitive markets. This was evidenced by new technology adopted by new entrants as well as new corporate strategies, which could only have resulted from the governments' retreat from market-distorting regulations, thereby producing a "market-friendly" environment. ${ }^{14}$

The other perspective, a government-led notion of development, has intellectual antecedents in "developmental state" conceptions of postwar growth in Northeast Asia. ${ }^{15}$ From this perspective, governments can do much to foster growth and promote economic competitiveness, even in the face of globalization. ${ }^{16}$ Japan and Korea developed largely as a result of government activity to shape their economies; their crises in the 1990s were not necessarily inevi-

12. Arguments about states becoming irrelevant include Susan Strange, The Retreat of the State: The Diffusion of Power in the World Economy (New York: Cambridge University Press, 1996); Kenichi Ohmae, End of the Nation State: The Rise of Regional Economies (New York: Free Press, 1996); Manuel Castells, The Rise of the Network Society (Malden, Mass.: Blackwell Publishers, 1996).

13. For scholarship before the 1990s, see Wade, "East Asia's Economic Success." For Japan, see Richard Katz, Japan: The System That Soured: The Rise and Fall of the Japanese Economic Miracle (New York: M. E. Sharpe, 1998). For Korea, see Linda Weiss, The Myth of the Powerless State (Ithaca, N. Y.: Cornell University Press, 1998); Meredith Woo-Cumings, "The State, Democracy, and the Reform of the Corporate Sector in South Korea," in The Politics of the Asian Economic Crisis, ed. T. J. Pempel (Ithaca, N. Y.: Cornell University Press, 1999).

14. OECD, “OECD Economic Surveys 1999-2000: Korea” (Paris: OECD, 2000); Don-Wan Tcha, June S. Park, Suk-Gwon Chang, and Kwan Ho Song, "Korean Telecommunication Industry in Transition," Telecommunication Systems 14:1 (August 2000), pp. 3-12; Nae-Chan Lee, "Broadband Internet Service: Korea's Experience," report (Seoul: Korea Information Society Development Institute, 2002); Jyoti Choudrie and Heejin Lee, "Broadband Development in South Korea: Institutional and Cultural Factors," European Journal of Information Systems 13:2 (June 2004), pp. 103-14.

15. For an overview, see Wade, "East Asia's Economic Success."

16. For example, see Jonah Levy, ed., The State after Statism: New State Activities in the Age of Liberalization (Cambridge, Mass.: Harvard University Press, 2006); Weiss, "The Myth." 
table consequences of these interventions. ${ }^{17}$ This perspective points to the history of extensive government involvement in the telecommunications sector, spanning from initial government investment in costly networks to dealing with privatized former state-owned carriers. Given this background, this perspective predicts that rapid broadband development resulted from the two governments strategically altering investment profiles to foster rapid broadband diffusion. ${ }^{18}$

Existing analyses of the two countries' broadband development provide a confusing and contradictory picture. While the market-led analyses argue that the governments retreated from markets, government-led analyses contend essentially the opposite - that the governments actively intervened in them. Worse yet, some analyses conflate both market-led and government-led perspectives. ${ }^{19}$ As we will show empirically throughout this paper, the market-led explanations tend to ignore bountiful examples of re-regulation, while stateled explanations tend to list government programs and outcomes with little regard for market dynamics. Both tend to downplay the political dynamics driving policies and regulatory regimes as well as the trajectories of regulatory and institutional change.

Both the market-led and government-led perspectives of growth are merely that, perspectives. Each finds evidence to support its view. In this study we examine precise interactions between governments and markets over time to reconcile these perspectives and to accurately compare and contrast Korea's and Japan's broadband development. In focusing on the nature of governmentmarket interactions, we recognize the following:

17. See Robert Wade, "Wheels within Wheels: Rethinking the Asian Crisis and the Asian Model," Annual Review of Political Science 3 (June 2000), pp. 85-115; Steven K. Vogel, Japan Remodeled: How Government and Industry Are Reforming Japanese Capitalism (Ithaca, N. Y.: Cornell University Press, 2006).

18. Martin Fackler, "In Korea, Bureaucrats Lead the Technology Charge," New York Times, March 16, 2006; Rob Frieden, "Lessons from Broadband Development in Canada, Japan, Korea, and the United States," Telecommunications Policy (September 2005); Choongok Lee and Sylvia M. Chan-Olmsted, "Competitive Advantage of Broadband Internet: A Comparative Study between South Korea and the United States," ibid., 28 (October-November 2004), pp. 649-77; Heejin Lee, Robert M. O'Keefe, and Kyounglim Yun, "The Growth of Broadband and Electronic Commerce in South Korea: Contributing Factors," Information Society 19 (January 2003), pp. 8193; Tcha et al., "Korean Telecommunication Industry in Transition"; Choudrie and Lee, "Broadband Development in South Korea"; for Japan: Thomas Bleha, "Down to the Wire," Foreign Affairs 84:3 (May-June 2005), pp. 111-24; Mark Tilton, "Neoliberal Capitalism in the Information Age: Japan and the Politics of Telecommunications Reform," Working Paper, no. 98 (Encinitas, Calif.: Japan Policy Research Institute [JPRI], 2004).

19. Tcha et al., "Korean Telecommunication Industry in Transition"; Lee, "Broadband Internet Service: Korea"; Choudrie and Lee, "Broadband Development in South Korea"; and OECD, "Economic Surveys: Korea." 
- markets often need sustained government interaction to function; ${ }^{20}$

- liberalization, an increase of rules, often comprises deregulation, a relaxing of rules, as well as reregulation, an increase in the number and scope of rules, ${ }^{21}$

- institutions can shape political dynamics; ${ }^{22}$

- the configuration of existing institutions and markets can affect the strategies available to governments attempting to manage them. ${ }^{23}$

Therefore governments may actively facilitate market-based competition on the one hand while retaining the capacity to act strategically in shaping, guiding, and limiting the scope of markets, on the other. This recognition allows us to explain the seemingly conflicting evidence supporting both the state-led and market-led perspectives. It also helps to differentiate liberalization for the sake of liberalization, from liberalization for the purpose of achieving particular goals - such as the development of broadband. In other words, it opens up the conceptual possibility for strategic liberalization, our contribution to the debate.

From this perspective, we do not expect that market outcomes were necessarily predetermined or micromanaged, but we do expect that liberalization was strategic, with both governments attempting to shape market competition in such a way as to foster broadband development.

\section{Institutional Origins and Political Dynamics: Privatization and Liberalization}

Much as in many Western European countries, the telecommunications sectors of both Japan and Korea began in the late 1800s under the auspices of direct government ownership and bureaucratic operation. State-owned monopoly corporations were later created, with a thrust toward liberalization and privatization since the 1980s. The politics of liberalization and privatization are the entry points for our analysis, allowing us to see how institutions and politics shaped the trajectory of sectoral policymaking, institutional change, and government-market interactions.

Japan's privatization of its state-owned monopoly, Nippon Telegraph and Telephone (NTT), was a politically messy affair involving a reconfiguration of power between institutional actors. By contrast, Korea's privatization of Korea Telecommunication Authority (KTA) was a relatively smooth process, followed by a politically driven initiative to strengthen the lead bureaucracy.

20. Karl Polanyi, Great Transformation: The Political and Economic Origins of Our Time (Boston, Mass.: Beacon Press, 1944).

21. Steven K. Vogel, Freer Markets, More Rules: Regulatory Reform in Advanced Industrial Countries (Ithaca, N. Y.: Cornell University Press, 1996).

22. Suzanne Berger, Peasants against Politics (Cambridge, Mass.: Harvard University Press, 1972), pp. 145-77.

23. John Zysman, Governments, Markets, and Growth: Financial Systems and the Politics of Industrial Change (Ithaca, N. Y.: Cornell University Press, 1983). 
These differences were driven by the initial institutional configurations and ensuing political dynamics of the telecoms sectors in both countries.

\section{Japan: The Political Battle over NTT}

In Japan, the political battle over privatizing NTT and liberalizing the telecoms sector was complex and contentious, involving a dramatic power grab by the Ministry of Posts and Telecommunications (MPT). In 1889 officials created the Ministry of Communications (MOC) to construct and operate Japan's telecommunications networks. After the Pacific War, MOC was disbanded by the Allied Occupation because of its role in promoting propaganda. In 1952, after political wrangling, the telecoms functions of MOC were transferred to NTT, which was newly established as a public corporation.

NTT reigned as the sector's dominant actor until the $1980 \mathrm{s.}^{24}$ Although it was formally under the jurisdiction of MPT, NTT could essentially regulate itself because it had inherited prewar MOC staff, whereas the ministry, which had been created from the Ministry of Postal Affairs, lacked personnel and expertise. Thus, NTT personnel sent to MPT were often in charge of evaluating NTT's requests. ${ }^{25}$ Second, NTT received budget allocations directly from the Diet, depriving MPT of funding-allocation policy tools of the sort used by the Ministry of Finance (MoF) and the Ministry of International Trade and Industry (MITI). Third, NTT also used its substantial research and development (R\&D) budget to keep a group of equipment suppliers, the "NTT family"including firms such as NEC, Fujitsu, and Oki - as manufacturers of products tailored to its own specifications. ${ }^{26}$

The battle over NTT's privatization was fought in the early 1980s among actors including the Second Administrative Reform Commission (Rinji Gyosei Kaikaku Suishin Shingikai, Rincho), MPT, NTT, MoF, NTT "family" firms, retired NTT executives, NTT's union (Zenkoku Denki Tsushin Jugyoin Kumiai, Zendentsu), and several key Liberal Democratic Party (LDP) politicians. This battle was closely intertwined with a bureaucratic turf war between MITI and MPT over jurisdiction of the rapidly expanding telecoms sector. This clash involved many of the same political actors, with MPT leaning heavily on policy specialist politicians from the ruling LDP (zoku ["tribe"] politicians) and MITI lobbying the U.S. to apply diplomatic pressure on its

24. For details, see Vogel, "Freer Markets," pp. 137-45.

25. Chalmers Johnson, "MITI, MPT, and the Telecom Wars: How Japan Makes Policy in High Technology," in Politics and Productivity: How Japan's Developmental Strategy Works, ed. Chalmers Johnson, Laura Tyson, John Zysman (New York: Harper Business, 1989), p. 190.

26. See Marie Anchordoguy, "Nippon Telegraph and Telephone Company and the Building of a Telecommunications Industry in Japan," Business History Review 75 (Autumn 2001), pp. 50741; Martin Fransman, Japan's Computer and Communications Industry: The Evolution of Industrial Giants and Global Competitiveness (New York: Oxford University Press, 1995). 
CHART 1 The Evolution of Japan's Lead Bureaucracy and Incumbent

\begin{tabular}{llll}
\hline Prewar & $\rightarrow \frac{\text { Postwar-1985 }}{\text { NTT Public Corp. }} \rightarrow \frac{1985-}{\text { NTT (NTT Holding Co. }}$ \\
Ministry of Postal Affairs & $\rightarrow \begin{array}{l}\text { MPT (administrative } \\
\text { bureaucracy) }\end{array}$ & $\rightarrow$ MPT (policy bureaucracy)
\end{tabular}

SOURCE: By authors.

side. This battle has been chronicled elsewhere, but in short the outcome was a dramatic gain in regulatory authority and policymaking power by $\mathrm{MPT}^{27}$

MPT succeeded in rising from a "regulatory" bureaucracy with largely nominal power to a full-fledged "policy" bureaucracy capable of MITI-style industrial policy and strategic sector management, as we will see. NTT escaped total breakup, the fate of America's AT\&T, and although significantly weakened, the Japanese firm maintained significant policy clout in the market.

This reversal in MPT's and NTT's power relations set up the political dynamics that drove Japan's telecoms policymaking thereafter. MPT continually battled NTT to exert power over a variety of issues, arguing in 1990 and 1996 that the latter should be broken up. NTT resisted, sometimes mustering political support within the LDP to negotiate compromises. ${ }^{28}$ The government is still slowly divesting itself of NTT, 20 years after the initial privatization.

\section{Korea: Hierarchy and the Creation of a Strong Lead Bureaucracy}

In Korea, the politics of privatization and liberalization was relatively smooth compared to the case in Japan (see Chart 1), largely because of the superior strength of the lead bureaucracy vis-à-vis the incumbent. Beginning in 1948, the MOC directly operated telecoms services until 1981, when it spun off KTA as the state-owned monopoly carrier. However, KTA did not have the policymaking clout or supplier domination that Japan's NTT had enjoyed: real power, expertise, and oversight remained with MOC.

The privatization of KTA, which took from 1987 until 2002, was undertaken cautiously, hand in hand with the government's attempt to manage the liberalization process. In 1997 the government abolished the KT (Korea Telecom)

27. Vogel "Freer Markets"; Johnson, "MITI, MPT, and the Telecom Wars"; Kenji Kushida, "The Politics of Restructuring NTT: Historically Rooted Trajectories from Actors, Institutions, and Interests," Stanford Journal of East Asian Affairs 5:2 (Summer 2005), pp. 29-36.

28. For details, see Eiji Kawabata, "Dual Governance: The Contemporary Politics of Posts and Telecommunications in Japan,” Social Science Japan Journal 7:1 (April 2004), pp. 21-39. 
Law that had governed KTA's activities. KTA renamed itself Korea Telecom in 2001. The government's primary concern was to slowly divest itself from KTA, thereby retaining direct management control over the sector until officials' vision for competition among three carrier groups was realized. ${ }^{29}$

The political bargaining process for privatization was relatively simple. For example, an accord was reached with KTA's labor union to limit foreign ownership in order to protect employment, in line with Korea's restrictive overall strategy toward foreign investment. MOC's privatization plans received strong political backing, including from Presidents Roh Tae-Woo (1987-93) and Kim Young-Sam (1993-98), the Economic Planning Board (EPB), the Ministry of Finance and Economy (MoFE), and the chaebol. The government, wary of the chaebol gaining disproportionate influence in the sector, limited chaebol ownership of KTA to $5 \%$ until the final stages of privatization. ${ }^{30}$

In 1994 a politically driven focus on coordinating IT (Information Technology) policy further strengthened the Korean telecommunications lead bureaucracy. Part of the impetus was an ideational cleavage over liberalization, complicated by bureaucratic jurisdictional issues. Though far from fighting the politicized turf war between Japan's MPT and MITI, Korean bureaucrats in the 1980s divided over the merits of market-led versus state-led liberalization. Policy coordination became somewhat difficult because this cleavage overlapped with competing policy jurisdictions among the MOC, the Ministry of Trade, Industry, and Energy (MoTIE), and the Ministry of Science and Technology (MST) (the latter was responsible for software industrial policy). The Kim Young Sam administration's answer was to expand the power, jurisdiction, and functions of MOC by creating the MIC (Ministry of Information and Communications) (Korea) and giving it exclusive jurisdiction of the telecoms sector, absorbing the industrial policy functions from MoTIE and MST. ${ }^{31}$

A series of politically driven policies - the "Framework Act on Informatization Promotion" in 1995 and an "Information Promotion Fund" in 1996strengthened MIC's legal and financial tools. Moreover, MIC ministers, appointed by the president, were experts in IT, facilitating decisive policymaking

29. Dal Yong Jin, "Political and Economic Processes in the Privatization of the Korean Telecommunications Industry: A Case Study of Korean Telecom: 1987-2003," Telecommunications Policy 30:10-11 (November-December 2006), pp. 3-13.

30. Although privatization did not go exactly according to government plans, its main objectives were fulfilled. In 2000 , the government raised the foreign ownership ceiling to $49 \%$, fearing adverse effects on the stock market after the financial crisis, but no foreigner owned more than $10 \%$. In 2002, SK Telecom (SKT) aggressively bought over $10 \%$ of KT, taking advantage of regulatory changes allowing chaebol to own up to $15 \%$, but the government, intending for three chaebol to own 5\% each, successfully pressured SKT to reduce its shares. See ibid.

31. For details, see Hong Sung Gul, "The Political Economy of the Korean Telecommunications Reform,” Telecommunications Policy 22:8 (September 1998), pp. 697-711. 
CHART 2 The Evolution of Korea's Lead Bureaucracy and Incumbent

\begin{tabular}{lllll}
\hline MOC & & & & \\
$(1948-81)$ & $\rightarrow$ & KOC (1981-1994) & $\rightarrow$ & MIC (1994-) \\
& & & $\rightarrow$ & KT (1997-)
\end{tabular}

SOURCE: By authors.

and strengthening the legitimacy of the ministry's policies. ${ }^{32}$ The contrast with Japan is clear, because the ministers of Japan's MPT tended to be politicians without expertise in IT who received Cabinet positions according to political logic. Bureaucrats, usually less disposed to enacting decisive change, were the experts. Thus, the initial institutional arrangements, which shaped the actors and political dynamics, differed between Korea and Japan (see Chart 2). However, the policy regimes that each developed for managing liberalization were remarkably similar.

\section{The Regulatory Frameworks: "Managed Competition" Regimes}

In the initial phases of liberalization, the regulatory regimes of Japan and Korea were geared toward "managing" competition. The term "regulatory regimes" refers to the policies, regulations, and institutions that shape the terms of market competition and private actors' incentives and constraints. Both countries had a strong lead bureaucracy that compartmentalized the sector, orchestrated new competitors, and micromanaged the terms of competition.

In Japan the Telecommunications Business Law governing the sector allowed MPT to divide carriers into three types based on whether they owned or leased infrastructure, with stronger regulations on infrastructure owners. ${ }^{33} \mathrm{MPT}$ also used administrative guidance to limit the scope of businesses to long distance, local, or international. ${ }^{34}$ A "Supply-Demand Adjustment" clause in the

32. The first minister of MIC, Sang-Hyon Kyong, with a Ph.D. from MIT and experience at Bell Labs, became vice president of KT, president of the Korean government's Electronics and Telecommunications Research Institute (ETRI) and NCA, and vice minister of MOC. The recent minister, Dae-Je Chin, with an electrical engineering Ph.D. degree from Stanford, worked at HP Labs and IBM and was an executive at Samsung.

33. "Type I" owned infrastructure, "Type II" carriers leased facilities from Type I carriers, "Special Type II" carriers provided long distance services, and "General Type II" carriers offered local service.

34. Hidenori Fuke, Joho Tsushin Sangyo no Kozo to Kisei Kanwa: Nichibeiei Hikaku Kenkyuu [Structural change and deregulation in the telecommunications industry: A U.S.-U.K.-Japan comparative study] (Tokyo: NTT Shuppan, 2000). 
Telecommunications Business Law allowed MPT to orchestrate the entry of new competitors into the sector, empowering the ministry to deny entry by citing excess supply or insufficient potential demand, without citing specific criteria. MPT arbitrated interconnection rate negotiations for competitors to access NTT's infrastructure behind closed doors. Licensing authority also allowed MPT to manage prices set by carriers, giving approval only after carefully evaluating the expected effect of price change proposals. As a result, prices came down gradually and in lockstep, with competitors lowing their prices incrementally, soon followed by NTT. ${ }^{35}$

Korea's regulatory regime was quite similar, operating under a Telecommunications Business Law. The government compartmentalized the sector according to services (i.e., facilities based or value added) as well as service providers (which type of services they provided). ${ }^{36}$ Officials also divided the sector into international, long-distance, and domestic segments, gradually licensing new competitors in each. ${ }^{37}$ Between 1990 and 1994, the government generally permitted only services that it had approved (a "positive listing" system), and until 1997 applications for new licenses were accepted only during a stipulated window of time (a "request for proposal" system). ${ }^{38}$

In sum, telecommunications liberalization in both Korea and Japan entailed increasing the level of competition not simply by deregulation but also by reregulation: the creation of "managed competition" policy regimes to actively manage the dynamics of market competition.

Let us now move to the development of broadband, examining the interactions among politics, regulatory regimes, and market dynamics within these emerging markets. In the case of Korea, the frontrunner, we find that broadband developed within its existing "managed competition" regulatory regime. Japan, on the other hand, underwent a "regime shift," with broadband markets

35. For details, see Kenji Kushida, “Japan's Telecommunications Regime Shift: Understanding Japan's Potential Resurgence," in How Revolutionary Was the Digital Revolution? National Responses, Market Transitions, and Global Technology in the Digital Era, ed. John Zysman and Abraham Newman (Stanford: Stanford University Press, 2006), pp. 125-47; Fuke, "Structural Change and Deregulation," pp. 25-31; Vogel, "Freer Markets," pp. 161-66.

36. Categories for service providers changed several times as the government sought to find the optimum level of control over each type of provider, shifting from General/Specific/Valueadded (1990) to Facility-based/Value-added (1994), and Facility-based/Special/Value-added (1997). See Nae-Chan Lee and Han-Young Lie, "Korea's Telecom Services Reform through Trade Negotiations," in Trade in Services in the Asia-Pacific Region, ed. Takatoshi Ito and Anne O. Krueger (Chicago: University of Chicago Press, 2003).

37. In international service, DACOM (Datacommunications Company of Korea) was licensed in 1990, and Onsei in 1996; for long distance, DACOM in 1995 and Onsei in 1997. For local telephony, Hanaro was licensed in 1996.

38. For details, see Lee and Lie, "Korea's Telecom Services Reform." 
developing out of this process. We argue that differences in the politics driving telecoms policymaking spawned divergent regulatory regimes.

\section{Broadband in Korea: Managed Competition Regime}

The Korean government did not orchestrate broadband deployment from a master blueprint. However, its policies strongly shaped service providers and their strategies, and the government's desire for "facilities-based" competition was achieved. In order to foster network infrastructure buildouts, MIC used its newly acquired resources and policy tools. The Korea Information Infrastructure Initiative (commonly identified as KII), which operated from 1995-2005, included a variety of backbone-building and R\&D facilitation programs. ${ }^{39}$ MIC also offered financial support, granted preferential tax treatment to participants, and directly underwrote loans to service providers building their networks. ${ }^{40}$

Broadband service began in Korea in 1998 when Thrunet introduced broadband services over its cable infrastructure. After the government announced that it would license one firm to lease out cable infrastructure, Thrunet had been created in 1996 as a consortium of over 100 companies under the auspices of DACOM, the long distance new entrant. The principal shareholder was state-owned energy company KEPCO (Korea Electric Power Company), and when Thrunet commenced service with its own infrastructure it leased additional capacity from KEPCO. The latter, incidentally, had boldly gambled on building its own fiber optic infrastructure without explicit government permission. ${ }^{41}$ The fast, flat-rate broadband service quickly became popular.

The entrance of a startup firm, Hanaro, into the broadband market is usually considered the beginning of Korea's broadband explosion. Hanaro was formed

39. KII consisted of three parts: "KII-Government" built a nationwide backbone for broadband, "KII-Testbed" supported R\&D to bring technologies to market, and "KII-Private" aimed to facilitate market competition to spread broadband through private sector investment. Lee and Chan-Olmsted, "Competitive Advantage," pp. 658-59.

40. For example, see Choudrie and Lee, "Broadband Development in South Korea," pp. 106-07.

41. According to a prominent government official, the story behind KEPCO's fiber network is a check against the temptation to overrate Korean government's omnipotence. Around 1980, KEPCO installed fiber throughout its network, gambling that once it had the infrastructure, the government would be forced to allow KEPCO to use it more productively. This was interesting, given that KEPCO was fully government-owned and under the jurisdiction of the Ministry of Commerce and Industry (MCI). In the meantime, KT had created its own fiber networks with government support, partly financial. A dispute ensued when both KEPCO and KT applied for a license to lease fiber to telecom carriers. From a capacity standpoint, according to the government official, KT's infrastructure was sufficient, while KEPCO's was redundant. However, both KT and KEPCO were fully government owned at the time, and although MOC was pitted against MCI, they could not engage in a public battle because that would have revealed that MCI had allowed KEPCO to take matters into its own hands with taxpayers' money. 
in 1997 after MIC announced in 1996 that it would license exactly one competitor in the local telephony market. DACOM, KEPCO, and chaebol such as Samsung, LG, and Daewoo were initial investors, and Shin Yun-Shik, former vice minister of MPT and a top manager of DACOM, was one of the initial leaders. In an attempt to even the playing field, MIC compartmentalized KT's activities by prohibiting KT from subsidizing its local service with profits derived elsewhere. $^{42}$

Upon commencing local telephony services, however, Hanaro quickly found that competing against KT was tantamount to taking on Goliath barehanded. KT offered high quality services at competitive prices, and the lack of number portability - consumers lost their existing numbers when switching to Hanaro - gave Hanaro little to offer. Driven to desperation, Hanaro noted customer surveys revealing that KT's data service subscribers (including Internet services based on dial-up and ISDN) ${ }^{43}$ were dissatisfied with slow access and per minute access fees. DSL, utilizing existing copper infrastructure, and delivering higher speeds capable of flat rate fees, provided an irresistible opportunity for Hanaro.

The regulatory framework supported Hanaro's strategy to offer customers DSL, since Internet service provision was in a relatively unregulated segment of the market. It was considered a "value-added service" for facilities-based service providers, requiring neither permission nor licensing. Furthermore, in 1997 the government had switched from a "positive list" system, allowing only government-specified activities, to a "negative list" system, allowing providers to offer any non-prohibited services.

Thus, in April 1999 Hanaro commenced broadband services, utilizing both DSL and cable, using its own DSL network and leasing cable capacity from Powercomm, a subsidiary of KEPCO and $\mathrm{KT}^{4}{ }^{4}$ Hanaro broadband service sparked intense competition and a price shock by bundling broadband as a free addition to its basic telephone subscription - amounting to approximately $\$ 40$ per month with free installation. Propelled by this pricing, Hanaro acquired more than a million subscribers within 18 months.

Hanaro's jaw-dropping DSL success profoundly influenced KT's strategy. Unlike Japan's NTT, KT had only begun investing in ISDN. Fearing that it

42. Interview with former top MIC official, Berkeley, Calif., November 4, 2005.

43. ISDN was considered the next evolutionary stage in the telecommunications infrastructure to reach homes, until the advent of DSL rendered it obsolete. ISDN transmits voice and data over copper wires digitally, allowing for simultaneous voice and data transmission. It sported faster Internet connections than conventional dial-up but was far slower than DSL.

44. In cable services, the Korean government separated conduit and content. The two stateowned cable infrastructure owners, Powercomm and KT, were not permitted to offer services, instead leasing out capacity. Therefore, new entrants to the broadband market, such as Thrunet in 1998 and Hanaro in 1999, initially rented cable capacity. This structural separation rule was relaxed in 2000 when KT sold its cable infrastructure to cable service providers. 
TABLE 5 Total Subscribers of Broadband Carriers

\begin{tabular}{lrrr}
\hline Year & 1999 & 2000 & \multicolumn{1}{c}{2001} \\
\hline Thrunet & 142,168 & 760,999 & $1,317,624$ \\
Hanaro & 84,249 & $1,056,724$ & $2,070,552$ \\
KT & 12,903 & $1,730,977$ & $3,874,442$ \\
Others & 13,662 & 394,300 & 580,382 \\
$\quad$ Total & 252,982 & $3,943,000$ & $7,843,000$ \\
\hline
\end{tabular}

SOURCE: Internal documents from Government of Korea, MIC.

\begin{tabular}{lcccccc}
\hline TABLE & 6 & \multicolumn{7}{l}{ Market Shares of Broadband Carriers (\%) } \\
\hline & 1999 & 2000 & 2001 & 2002 & 2003 & 2004 \\
\hline Thrunet & 56 & 19 & 17 & 13 & 12 & 10 \\
Hanaro & 33 & 27 & 26 & 28 & 25 & 23 \\
KT & 5 & 44 & 49 & 47 & 50 & 55 \\
Others & 5 & 10 & 7 & 13 & 14 & 11
\end{tabular}

SOURCE: Ibid. to Table 5.

would be permanently left behind, KT quickly scrapped plans for further investments in ISDN and put its weight behind DSL, as users clearly preferred higher speeds, flat-rate fees, and always-on Internet access. ${ }^{45} \mathrm{KT}$ commenced DSL service in June 1999; competition intensified when other firms entered the market, such as SK Telecom in 1999 and Onse Telecom in 2000.

KT was able to quickly offer DSL nationwide, while Hanaro was limited in its geographic reach. KT's competitive pricing and rising Korean demand for broadband enabled it to quickly surpass Hanaro's market share by June 2000. KT has retained a dominant market share since (see Tables 5 and 6). Because DSL was in a relatively unregulated market segment, KT did not face policies designed to aid competitors at its expense. The smaller service providers never had a chance.

\section{Re-Regulation: Managed Competition, Continued}

The re-regulation of broadband by MIC is clear evidence that the Korean government sees its role as facilitating competition, in this case through the

45. From 1999 to 2000, ISDN subscribers shrank dramatically from 175,000 to 100,000, while DSL grew to over two million. OECD, "Source OECD Telecommunications Database, Vol. 2005," <www.sourceoecd.org >. 
existing regulatory regime, rather than deregulating or "opening" the market per se. After the initial burst of broadband growth, KT's domination of broadband caused serious problems for competitors. In 2002, Thrunet declared bankruptcy, and Hanaro found it increasingly difficult to sustain profitability. ${ }^{46}$ In 2004, deeming KT's dominance a barrier to competition, MIC stepped in, shifting the categorization of broadband service providers from a less-regulated segment ("value-added") to a more-regulated segment ("facility-based"). The government designated KT as the "dominant service provider" in broadband, subjecting it to stricter service and pricing regulations.

\section{Industrial Policy with a Twist}

It is notable that Korea's industrial policies toward broadband attempt not only to enhance supply-side investment in networks but to promote demand for their use as well. In its classical developmental strategy, Korea is usually considered to have been producer- rather than consumer-oriented. The strategy channeled Koreans' income into relatively centralized banking systems by keeping individual access to other avenues of investment-securities or offshore markets - relatively difficult and then channeling those savings into strategic sectors. The KII strategies fall in line with this classical industrial policy.

However, in promoting broadband and the Internet, the Korean government also enacted a series of demand magnification programs. Several programs were designed to facilitate Internet education, encourage computer use in schools and homes, offer computer-purchase assistance, and educate housewives who often control household finances. ${ }^{47}$ Perhaps the most clever demand magnification policy was to deeply embed computer literacy in Korea's ultra-competitive university entrance exams, making a home personal computer a necessity for any seriously education-minded parent. Computer literacy certification could convert to points in university entrance exam scores. Broadband access became part of the package for computer literacy, driving subscriptions for households with school-age children. ${ }^{48}$ Although the effectiveness of

46. In early 2005, Hanaro absorbed Thrunet but still had difficulty, even contemplating receiving foreign funds to stay afloat (Fransman, Global Broadband Battles, p. 32).

47. Programs include the "Ten Million People Internet Education Project (2000-02)," the "One Million Housewife Digital Literacy Education Project," and the "PC for Everyone" program (1999). The government subsidized approximately 1,000 private training institutes to educate housewives to promote demand in households and provided low-priced PCs, partly through an installment program via the postal savings system and through subsidies and leases for PCs/broadband to low-income citizens (MIC, "White Paper 2001" [Seoul: Ministry of Information and Communications]). The government offered discounts for Internet access by primary and secondary schools, leading to $100 \%$ broadband penetration in schools by late 2000 - though, of course, how it is used is another matter (Choudrie and Lee, "Broadband Development in South Korea," p. 107).

48. For an overview, see Izumi Aizu, "A Comparative Study of Broadband in Asia: Deployment and Policy," discussion paper (Tokyo: Center for Global Communications, International University of Japan, 2002). 
these programs and policies in promoting broadband cannot be determined decisively, the range of demand magnification industrial policies beyond the usual supply-side enhancements is certainly noteworthy.

\section{Broadband in Japan: An Outgrowth of Regime Shift}

\section{Policy Drivers}

In stark contrast to Korea's broadband development, which occurred within the "managed competition" regulatory regime, Japan's broadband markets grew out of a transition away from this approach. The regime shift was driven by the political dynamics of MPT (reorganized in 1999 and renamed the Ministry of Internal Affairs and Communications, MIC [Japan]), which continually battled NTT, and by efforts from Japan's newly strengthened Cabinet Office to promote IT. The shift entailed the government's relinquishing many competition management policy tools while adding new institutions and regulations in a transition from ex ante to ex post regulation.

The gradual transformation began in the late 1990s. In 1996, the battle between MPT and NTT over whether and how to break up NTT, ongoing since the early 1980s, reached a settlement. To give a flavor of the complexity of negotiations producing the political compromises of 1983, 1990, and 1996, the list of participants included MPT, NTT, the LDP, the prime minister, NTT's labor union, the Social Democratic Party, the Fair Trade Commission (FTC), the Keidanren (Japanese Business Federation), MoF, MITI, NTT's competitors, "family" firms, and numerous deliberation councils. ${ }^{49}$

The 1996 outcome was a surprise agreement between MPT and NTT that left the latter a single corporate entity by turning it into a holding company. The tortured nature of this political compromise may be inferred by the fact that it required lifting of the post-war ban on holding companies, a key tenet of the Allied Occupation. Telecommunications Deliberation Council members learned of this compromise in newspapers, after thinking they had secured an agreement for NTT's complete breakup. ${ }^{50}$

With the NTT divestiture battle settled, MPT began further liberalization through both deregulation and re-regulation. In 1997, Japan signed the World

49. See Erik Bohlin, “Editorial: Restructuring Japan's Telecommunications,” Telecommunications Policy 21:2 (1997), pp. 79-84; Steven K. Vogel, “Creating Competition in Japan's Telecommunications Market,” working paper (Washington, D.C.: Japan Information Access Project, 2000).

50. Interview by Kenji Kushida with Toshihiko Hayashi, former member of the Telecommunications Deliberation Council, Stanford, Calif., May 2001. Nakamura Ichiya, former MPT official, contends that the sudden compromise was the result of MPT shifting its focus from battling NTT to battling NHK (Nippon Hoso Kyokai, Japan Broadcasting Corporation), the state-owned broadcaster under its jurisdiction. Interview by Kenji Kushida with Nakamura Ichiya, Stanford, Calif., May 2001. 
Trade Organization (WTO) Telecom Agreement, removing most restrictions on inward foreign direct investment (FDI), especially foreign ownership of infrastructure. ${ }^{51}$ In 1998 when these new rules took effect, MPT also relaxed several licensing requirements. ${ }^{52}$ This required amending the Telecommunications Business Law, a task facilitated by broad political support spearheaded by the Cabinet Office through the "Three Year Action Plan for Deregulation" of 1994. ${ }^{53}$

Interconnection to NTT's infrastructure, necessary for most competitors because NTT controlled the last-one-mile of infrastructure, had been a contentious political issue since initial liberalization in 1985. MPT's basic stance, periodically backed by U.S. pressure, was to force NTT to lower interconnection rates. In 1998, partly because of pressure from foreign firms operating in Japan, MPT adopted clear rules and a specific formula for interconnection. ${ }^{54}$

\section{Market Interactions in Early DSL Markets}

The next phase of the regime shift in Japan was driven by several factors: various government actors, interaction between new market entrants attempting to offer DSL, and a political drive for IT to catch up not only to the West but also to Korea. In this phase the liberalization was strategic in that the government, while reacting to market developments, clearly pushed for broadband diffusion.

In 1999, the startup firm Tokyo Metallic, followed by others such as Fusion Communications and eAccess, began offering DSL service. To do so, they needed to place equipment within NTT's switching facilities, a process known as "collocation." 55 Unlike Korea's Hanaro, these startup firms did not own infrastructure and unfortunately for them, Japan's interconnection rules established in 1998 did not cover collocation. The competitor firms were essentially operating in unregulated territory and therefore, predictably, were at the mercy of NTT. The latter delayed access and charged high fees, preferring to prioritize its per-minute, fee-based ISDN service with future plans to offer a proprietary fiber optic service. ${ }^{56}$

51. For details, see Kushida, "Japan's Telecommunications Regime Shift.”

52. For Type I carriers, most price changes and market entry shifted from "approval" to "notification." See Fuke, "Structural Change and Deregulation."

53. Yuko Suda, “Japan's Telecommunications Policy: Issues in Regulatory Reform for Interconnection," Asian Survey 45:2 (April 2005), pp. 241-57.

54. Kushida, "Japan's Telecommunications Regime Shift”; Fuke, "Structural Change and Deregulation," pp. 43-45; Vogel, "Creating Competition.” The formula, LRIC (long run incremental cost), was revised in 2000 to further favor competitors.

55. DSL sends high frequency signals over copper telephone lines, requiring equipment on both the user's side (the box at home) and inside the carrier's facilities (NTT switching stations).

56. NTT invested approximately nine billion dollars in its ISDN infrastructure. Robert Cole, "Telecommunications Competition in World Markets: Understanding Japan's Decline," in How Revolutionary Was the Digital Revolution? eds. Zysman and Newman, citing Nezu (2002). 
A series of government actions rapidly improved the competitive landscape for DSL providers. First, in July 2000, alarmed at Japan's lagging performance in Internet penetration, usage, and broadband diffusion, the political leadership initiated a policy drive to catch up in IT. The Cabinet Office, newly strengthened in its policymaking capacity as mentioned above, established an internal "IT Strategy Headquarters." "57 It produced the "e-Japan strategy," explicitly recognizing Japan's late start in IT and stipulating a timeline to create a market environment providing low-cost fast Internet access. ${ }^{58}$ Later that year, the Cabinet Office passed the "Basic IT Law," giving MIC a broad framework to promulgate ministerial ordinances. ${ }^{59}$

Second, in October 2000 the FTC made a rare foray into telecoms policymaking by issuing a warning to NTT over its treatment of DSL providers. MIC also revised several ministerial ordinances, compelling NTT to clarify its terms and fee calculation methodology for collocation. The ministry also forced NTT to lease out its unused fiber optic infrastructure ("dark fiber") at low prices to competitors and allow them access to its local "last-mile" infrastructure (known in the industry as "unbundling the local loop"). ${ }^{60}$

In 2001, MIC established the Dispute Resolution Commission (DRC), located within the ministry but mandated to reveal all deliberations to the publica shift away from the negotiated settlements behind closed doors. Among the early cases were DSL providers' complaints about NTT's sluggishness on collocation, with the DRC ruling against NTT. ${ }^{61}$ In 2003, MIC continued to deregulate by abolishing most of the registration and notification requirements, removing the classification scheme altogether, and announcing that it would not limit the scope of carriers' activities. ${ }^{62}$ In essence, MIC said that it would no longer compartmentalize the sector, thereby relinquishing most policy tools for micromanaging competition.

57. The Cabinet Office gained personnel and expanded policymaking capabilities. T. J. Pempel, “A Decade of Political Torpor: When Political Logic Trumps Economic Rationality," in Beyond Japan, ed. Peter Katzenstein and Takashi Shiraishi (Ithaca, N. Y.: Cornell University Press, 2006).

58. Government of Japan, IT Strategic Headquarters, Cabinet Office, < http://www.kantei.go. jp/foreign/policy/it/enkaku_e.html>, accessed May 23, 2006. Tilton argues that the "e-Japan" strategy is a classic "industrial policy" with a catch-up objective, explicit goal, and timeline to achieve specific outcomes. Tilton, "Neoliberal Capitalism."

59. Ministerial ordinances are legally binding but under the ministry's discretion, eliminating the need for coordination with actors such as the Ministry of Justice. In the 2000 government reorganization, MPT merged with other bureaucracies to become the Ministry of Public Management, Home Affairs, and Posts and Telecommunications (MPHPT). In 2004, it simplified the English name to "Ministry of Internal Affairs and Communications."

60. See Kushida, “Japan's Telecommunications Regime Shift”; Hidenori Fuke, "The Spectacular Growth of DSL in Japan and Its Implications,” Communications \& Strategies 52 (2003), pp. 175-91.

61. DRC website (meeting minutes in Japanese), <http://www.soumu.go.jp/hunso/>, accessed May 15, 2006.

62. Fuke, "Structural Change and Deregulation." 
Thus, by 2001 the competitive landscape facing Japanese DSL providers had changed considerably since the 1999 inception of Japan's broadband market. A whole set of regulations, with political backing, now supported DSL providers. Son Masayoshi, an ethnic Korean born in Japan and educated at the University of California, Berkeley, and founder of Softbank in the 1980s, pushed this new regulatory and market environment furthest.

Softbank, an early investor in Yahoo!, entered the DSL market through its subsidiary, Yahoo!BB, in September 2001. It launched a price war, offering monthly subscriptions at approximately half the market rate (2,400 yen, approximately $\$ 22$, versus around 5,000 yen). Softbank engaged in aggressive marketing, handing out $\$ 100$ DSL modems free at train stations. The firm's DSL became the cheapest service worldwide, sparking rapid DSL adoption and forcing other providers and NTT to lower their prices. ${ }^{63}$ Son then delivered a second price shock by bundling free IP (Internet Protocols) telephony subscriptions with its DSL, allowing free calls between Softbank subscribers and a long-distance flat rate to call non-subscribers, plus international calls at a fraction of the prevailing market rate. ${ }^{64}$ Softbank could offer this pricing because it leased dark fiber from NTT to create its own backbone based on IP, the scheme for data transmission underlying the Internet as we know it today, rather than conventional telephony.

MIC policy supported the sudden public interest in IP telephony surprisingly quickly. It not only assigned a dedicated array of telephone numbers (a 050 prefix) to IP telephones but went further to allow IP telephony services that satisfied certain quality requirements to receive conventional telephone numbers. ${ }^{65}$ This narrowed the gap between IP telephones and conventional telephony, making them closer to being substitutes.

\section{FTTH: Industrial Policy Origins with DSL-Influenced Market Dynamics}

Softbank's market strategy in DSL profoundly affected Japan's nascent FTTH service market. With extensive investment by NTT and encouraged by industrial policy measures such as subsidies and Development Bank of Japan loans,

63. Son's aggressive pricing surprised competitors and MIC officials. Many worried that the price war threatened future investment. It is doubtful that Son could have waged such a dramatic price war under the "controlled competition" regime.

64. Flat-rate telephony was new to Japan due to NTT's interconnection fees and dominance of the last-one-mile. Softbank IP telephony calls to the U.S. were 8 yen/min (6-7 cents), compared to the prevailing 200-300 yen $/ 3 \mathrm{~min}$.

65. "IP denwa demo bangou ga kawaranai riyuu" [Why numbers don't change with IP telephony], Nikkei Communication (November 2003), pp. 66-68. Some officials contend that MIC could quickly support IP telephony because the technology was relatively unknown and NTT didn't think to protest, because none foresaw IP telephony's rapid spread. 
Japan's fiber infrastructure buildout since the early 1990s was extensive. Just as DSL markets were taking off, fiber had reached the last-one-mile of most urban areas in Japan. ${ }^{66}$

NTT had planned to offer an expensive proprietary service combining video, telephony, and data but not based on Internet Protocols (TCP/IP). ${ }^{67}$ The government's failure to completely break up NTT actually gave the firm the financial strength to deploy FTTH nationwide. ${ }^{68}$ However, NTT was preempted by Usen, a landline music broadcaster with its own urban telephone pole and fiber infrastructure. In March 2001, Usen began offering household FTTH services at speeds close to $100 \mathrm{mbps}$ (versus $2 \mathrm{mbps}$ to $15 \mathrm{mbps}$ for DSL) for approximately 6,000 yen per month (approximately $\$ 50$ ), only slightly more than double the price of Softbank's DSL. Other competitors, including subsidiaries of power companies, began to enter the FTTH market with similar prices, dashing NTT's hopes for the expensive, proprietary service. ${ }^{69}$ FTTH providers also began offering IP telephony, accelerating household IP telephony adoption. ${ }^{70}$ In sum, the advent of low-priced FTTH services is best characterized as being rooted in NTT's traditional pattern of investment and "controlled competition" regime industrial policy, but being strongly shaped by the dynamics of the DSL service market.

\section{Conclusion}

Let us now summarize our findings, addressing our initial question of how exactly the governments, markets, and politics interacted in Japan and Korea as their broadband markets developed rapidly. First, at a market level, in both countries, new entrants pioneered broadband, delivering price shocks to Internet access - especially Hanaro for Korea and Softbank for Japan. The wild success of these newcomers forced the incumbents, KT and NTT, to realign their strategies and deploy DSL. Neither government micromanaged the specific market dynamics. So far, we agree with market-led expectations.

Second, our close study of the policies shows that, in both countries, the governments' approach toward liberalization (increasing the level of competition) was a deliberate strategy of both deregulation (relaxing rules) as well as reregulation (strengthening rules). Here, we disagree with simple market-led

66. By the end of 2001, metropolitan coverage of FTTH was 95\% (MIC, "White Paper," 2003).

67. See Kushida, "Japan's Telecommunications Regime Shift."

68. Takanori Ida contends that NTT DoCoMo's success in cellular markets provided NTT regional carriers de facto subsidies. Takanori Ida, "Broadband, the Information Society, and National Systems," in Global Broadband Battles, pp. 65-86.

69. Competitors included K-Opticom, a subsidiary of Kansai Electric Power Company; TT Net, a subsidiary of Tokyo Electric Power Company; and KDDI.

70. "Peer-to-peer" IP telephones (excluding computer to computer IP telephony such as Skype) grew from 4.3 million at the end of 2003 to 10 million by March 2006. MIC, Joho Tsushin Hakusho [Information and communications white paper 2006] (Tokyo: MIC, 2006), p. 112. 
explanations of government-market interactions. Both countries set up "managed competition" regimes with similar policy tools to orchestrate competition into the sector and to incrementally increase and adjust levels of competition.

The Korean government, in allowing Hanaro to enter the local telephony market, was not "opening" the market per se. Rather, it used the existing regulatory framework to introduce one competitor to KT. Later, when the government deemed insufficient the level of competition in the broadband market, it shifted the Internet service provider subsector into a more regulated sectoral "compartment" to strengthen its authority over KT.

In Japan the regime shift involved deregulation, as the government dismantled several policy tools of competition management. However, the regime shift also entailed significant reregulation, creating new institutions such as the DRC for ex post facto regulation and promulgating new policies to facilitate local loop unbundling and collocation. Regulatory support for IP telephony was quick, aiding the spread of broadband. ${ }^{71}$

Thus, we differ from the strongest of state-led expectations by being careful not to exaggerate the effect of state policies. Rather, we show how such policies interacted with market developments, the speed of which often startled government officials. However, the broad goal of each government to facilitate the deployment and diffusion of high-speed Internet access was firmly entrenched in their policy orientations, and both governments actively attempted to facilitate competition as a means rather than an end. Put simply, they engaged in strategic liberalization.

We also discovered significant divergence in the two countries' regulatory regimes, a reality not obvious in previous analyses. While Korea used its existing policy framework to facilitate strategic liberalization, Japan underwent a regime shift that altered institutions and policy tools. We contend that the politics driving each of the regulatory regimes best accounts for this divergence. Beginning with different institutional configurations at the point of origin for the telecoms sector, different political bargains at major junctures led to distinct sets of political dynamics, causing different outcomes at subsequent junctures. Korea's lead bureaucracy was able to establish early on a strong hierarchical relationship with a relatively weak incumbent and was later further strengthened by a political focus empowering the ministry. Japan's telecoms

71. It is debatable whether IP telephony should be considered a "disruptive technology" à la Christensen (2000). As Steven Weber contends, Christensen's definition of disruptive technology is problematic because it depends on the capacity of incumbent businesses to adapt their business models to the new technology. If incumbents successfully adapt to the new technology, it is not a "disruptive technology" per se. The true conceptual definition should rely on incumbents' business models rather than the technology. Clayton Christensen, The Innovator's Dilemma: When New Technologies Cause Great Firms to Fail (New York: HarperBusiness, 2000); Steve Weber, "Christensen Right and Wrong," QED 1 (December 2005). 
politics involved a more complex power struggle among the regulator, a more powerful incumbent, and various ministries and political actors and interests, resulting in a long chain of negotiated settlements.

As a building block for future scholarship, this comparative study raises further questions. If we were to consider the telecoms policies of Japan and Korea as comparatively successful in facilitating rapid development, then what differentiates this sector from other areas in which policy and market outcomes cannot be considered a success (for example, Japan's fiscal policies in the late 1990s)? Adequately addressing this question calls for a sharper focus within each country on differences in policy regimes, markets, and politics across sectors. One approach would be to map the political and institutional strengths of each government onto the technological paradigm and market attributes of particular sectors in order to evaluate the "fit." "72 Such a study would point to the strengths of the two countries' governments and institutions in fostering infrastructure investments and strategic regulatory support for particular technologies and market segments. We could see these strengths fitting DSL technology conducive to start-ups and new entrants, at a time when the Internet surged in economic and political importance, even as each country reevaluated its patterns of large-business driven growth.

Second, one might ask how broadband services fit into the broader ICT sectors? Our research is underway, and we tentatively suggest that differences in the set of policy tools available for landline and wireless, and in the relative strengths of market players vis-à-vis government, may create a distinct political dynamic in each subsector that varies by country. For example, Japan's telecommunications regime shift affects the wireless subsector differently, because MIC retains spectrum allocation as a powerful policy tool. In Korea, the politics of government-chaebol relations (involved in cellular handsets) differs from government-KT relations.

Let us conclude by noting that Japanese and Korean high-speed broadband environments have important implications for innovation and international competition in ICT. The process of sophisticated lead users putting technologies to serve new purposes was an essential component of the U.S.-initiated IT revolution. ${ }^{73}$ The U.S., a playground for experimentation and innovation in the initial phase of the Internet revolution, ${ }^{74}$ no longer boasts the most connected or fastest connected users. In the next round of innovation and international competition in IT network-enabled services, Japanese and Korean high-speed, broadband environments offer new "playgrounds" for experimentation and innovation.

72. See Steven Vogel and John Zysman, "Technology," in U.S.-Japan Relations in a Changing World, ed. Steven K. Vogel (Washington, D.C.: Brookings Institution Press, 2002).

73. Cohen et al., "Tools for Thought," esp. pp. 13-17.

74. Firms such as Microsoft, Cisco, Yahoo!, Amazon, Google, and eBay had enjoyed the most advanced and sophisticated domestic Internet market for their initial experimentation and innovation. 